\title{
The mobilization of the local in a public primary school in peri-urban Niamey, Niger
}

\section{Gabriella Körling}

\section{(2) OpenEdition \\ Journals}

Electronic version

URL: http://journals.openedition.org/apad/4062

DOI: 10.4000/apad.4062

ISSN: 1950-6929

Publisher

LIT Verlag

\section{Printed version}

Date of publication: 1 December 2010

Number of pages: 137-159

ISBN: 978-3-643-10535-6

\section{Electronic reference}

Gabriella Körling, «The mobilization of the local in a public primary school in peri-urban Niamey, Niger », Bulletin de l'APAD [Online], 31-32 | 2010, Online since 26 July 2010, connection on 07 September 2020. URL : http://journals.openedition.org/apad/4062 ; DOI : https://doi.org/10.4000/ apad.4062

\section{This text was automatically generated on 7 September 2020}

Bulletin de l'APAD 


\title{
The mobilization of the local in a public primary school in peri-urban Niamey, Niger
}

\author{
Gabriella Körling
}

\section{Introduction}

1 In this article I will address the theme of decentralization and the mobilization of the local through an analysis of public education provision in peri-urban Niamey. Anthropologicalstudies of public services in West Africa have illustrated the value of studying public service delivery and state administrations. These studies focus on everyday practices, interactions and social logics within these institutions, as a constitutive aspect of the state (Olivier de Sardan, 2004, 2005) addressing themes such as public health care (Jaffré \& Olivier de Sardan 2003) and corruption (Blundo \& Olivier de Sardan 2006). In a context in which the state is no longer the sole provider of public services, analytical attention should be paid not only to the production of public services by state administrations, but also to the "new spaces in which public services are produced" (Blundo \& Le Meur 2009 :14).Public service delivery is continuously reconfigured at the local level following the intervention of development actors, community organizations and private operators alongside that of the state administration (Blundo \& Le Meur 2009). This is not to assume that the state has ever been the sole provider of public services. However, the role of the state as public service provider has been challenged by the turn in international development discourse and policies from a state centered approach pushing for the importance of a strong state as the promoter of development,to a neoliberal ideology pushing for the withdrawal of the state in many public sectors in favour of privatization and an increasing role of civil society. Thisshift has consequences for the policies promoted in domains such as education and healthcare. Reforms geared towards decentralization 
and privatization, are a case in point. These tendencies are reinforced by the inability of the state to provide such public services on its own.

2 The overall aim of this article is to analyze the changing role of the state and the diversification of actors and institutions involved in public education provision. This is achievedusing a case study of a newly established public primary school in peri-urban Niamey, Niger, that was created with next to nothing in the way of infrastructure, furnishings and pedagogical material. The article will follow the daily 'management' of the public primary school, from its construction at the beginning of the school year to its literal dismantling at the end of the school year. As will be illustrated, this daily management - which often appeared as a struggle to make ends meet and to create a sense of certainty - opened up a space for the intervention of 'non state' actors such as neighborhood chiefs, elected district advisors, and international development projects. On the basis of the case study I will argue that the mobilization of the local in education provision involves a multiplicity of logics, strategies and interests on the part of different actors. And that the 'local community' so celebrated in development parlance, is difficult to locate on the ground. Moreover, the community structures assumed to represent the 'local community' - accorded a central place in education reform in both the financing and the management of schools - have little power and influence, and subsequently a very limited room for maneuver in carrying out the tasks they have been assigned in the name of decentralization and community participation. In addition to illustrating the changing configuration of public education provision at the local level, the case study is also revelatory of perceptions of the state. In a concluding reflection on the relation between the state and public education, I will suggest that despite the partial undoing of the role of the state in public service provision, the ideal of the state as service provider remains strong.

The article is based on 12 months of fieldwork in Niamey divided into two periods, between 2006 and 2008 conducted within the framework of a $\mathrm{PhD}$ thesis on public services, urbanization and the local state in urban Niger. Interviews as well as informal conversations with parents, pupils, teachers, traditional chiefs, NGO representatives, district and school inspection officials, and civil servants at the ministry of education, together with participant observation in schools form the core of the fieldwork material presented in this article ${ }^{1}$.

\section{The reconfiguration of public education provision}

4 Public education is traditionally an important sector of the state and considered as a state activity "in the standard image of the state" (Migdal \& Schilchte 2005 :33). In subSaharan Africa during the post independence period education was deemed as being central to the construction of the nation state and to economic development (Bierschenk 2007 :268). According to Bierschenk the definition of education as the exclusive domain of the state - a public good - was especially pervasive in Francophone Africa, both during the colonial period and after independence (Bierschenk 2007 :262). The post independence period saw the rapid development of education as enrolment rates increased dramatically (Lange $2003: 145$ ). However, the economic crisis of the 1980s put a halt to the development of the education sector. Meanwhile, the imposition of structural adjustment programs led to drastic cuts in public spending, education and health care, with the latter being especially hard hit (Henaff 2003 :167; Lange 2003 : 
145). The period of crisis led to an increase in donor funding for education and to an increasing influence of financial institutions such as the World Bank over national education policies (Lange 2003 :146). Donor influence increased yet again during the 1990s, a period which analysts of education policy have referred to as a period of consolidation of a 'global agenda on education' led by multilateral agencies such as the UNDP, UNICEF, UNESCO and the World Bank (King 2007).In a series of international conferences on education - in Jomtien in 1990, in Amman in 1996 and in Dakar in 2000 the international community committed to ensuring basic educationfor all (EFA). This commitment was reiterated in the United Nations Millennium Declaration and the Millennium Development Goals (MDGs) ${ }^{2}$ in which "education became part of the global development agenda" (King 2007 :378). The subsequent intensification of international intervention in national education systems and the homogenization of education policies has been referred to as the imposition of a new 'world school order' (ordre scolaire mondial) (Lange 2003) and as the transformation of education from a 'public good' (bien public), under national state responsibility, into a 'global good' or possession (bien global) (Bierschenk 2007).

5 Regarding the actual contents of education policy promoted by international agencies, the neoliberal paradigm that prevailed encouraged the retreat of the state, the increasing role of civil society and the introduction of market logics in the education sector. The restructuring of theeducation sector endorsed by international donors also included the promotion of decentralization. The most common argument for decentralization being that it will lead to a greater efficacy and a more parsimonious use of resourcesas administrative responsibilities are transferred from central authorities to the local level (Henaff $2003: 178$; Maclure $1994: 240$ ). It is also assumed to lead to an increased participation of local communities in education provision, a participation which it is argued will make schools more "attuned to community life" (Maclure 1994 :240) improving or re-establishing the links between school and local populations (Charlier \& Pierrard $2000: 31$ ).

6 In Niger the decentralization of the education sector was inscribed in the Losen (Loi 98-12 1Juin 1998, loi d'orientation du système éducatif), presented as the first all encompassing juridical or legal framework and orientation of the education system since independence (Daouda et al. $2001: 172$ ). In addition to declaring education a national priority and a right of all Nigerien citizens, the Losen stipulated the decentralization of the management of the education system and the increased implication of local communities, the beneficiaries of education services, in the management and financing of education ${ }^{3}$. The PDDE (Programme Décennal de Développement de l'Education), the national education program for the period 2003-2013, implemented in cooperationwith international donorsfollows along the same lines as the Losen ${ }^{4}$. The PDDE which is meant to harmonize all interventions in the education sector is divided into three components : access, quality and institutional development. Significantly, institutional development refers to the decentralization of the education system and includes the reorganization and reinforcement of the capacities of the Ministry of Education, of central and regional administrations and the creation of school committees (COGES) in all schools.In sum, education policy in Niger has been aligned to international directives encouraging the partial withdrawal of the central state from education services through the decentralization of the education sector. In the rest of this article I will focus on the effects of the reconfiguration of public 
education provision at the local level through an analysis of the practices and meanings that emerge in the daily 'management' of a public primary school in peri-urban Niamey.

\section{Uncertain beginnings : the creation of a public primary school}

7 Saga is situated on the eastern outskirts of Niamey on the bank of the river Niger that traverses the capital. Originally a village, it has attracted an ethnically and socioeconomically heterogeneous urban population that has bought land or rented housing. Saga is today the home of approximately 30,000 people, ${ }^{5}$ as well as the administrative capital of the canton of Saga that was created during the colonial period. Thirteen neighborhoods and villages are linked to the cantonal chieftaincy. Following the latest division of the urban municipality, the canton of Saga is completely contained by District Four of the urban municipality of Niamey. Although Saga is expanding, the industrial zone of Niamey physically separates it from the urban agglomeration and Saga is being overshadowed by recently established, faster growing and more dynamic neighbourhoods.From the city centre Saga is reached via a road which is frequented by taxis, minibuses, buses, trucks, bicycles and people on foot, and continues to the town of Kollo. The older parts of Saga - the quarters Saga Fondobon, Saga Gassia Kwara, Saga Sambou Kwara and Saga Gongou and the adjoining quarter Saga Kourtey - are located between the main road and the river. In these neighbourhoods the streets are crooked and narrow and extended family compounds in banco dominate. On the other side of the road more recently formed extensions of the older quarters stretch out, with wider and straighter streets and houses of concrete as well as banco. The edge of the river is lined with rice paddies. In the past Saga was known for the production of rice, however the productivity of the rice fields has started to dwindle. Agriculture is a traditionally dominant economic activity, however it is increasingly circumscribed to the rice fields and to market gardening along the river as customary land owners have sold farming land. Other economic activities have gained in importance due to the proximity of the city, including commerce and industrial work in the nearby industrial zone.

8 The first public primary school in Saga, called Saga 1, was created in the early 1960s. The school is located between a Friday mosque and a community library, near the residence of the canton chief. It is used for community meetings convened by the traditional chiefs. In 2007 there were four public primary schools as well as a public medersa (Franco Arabic school) and a public secondary school. Children could thus follow a full primary and secondary education cycle without having to go to the city centre. There were also one private primary school and two private secondary schools ; however the overwhelming majority of children enrolled in school attended public schools. During the school year 2006-2007 4,717 children were enrolled in public schools in Saga and only 317 in private schools.

The creation of the fourth public primary school coincided with my stay in the field in the autumn of 2006. The plans for the construction of the new school were announced to me by the neighborhood chief. The school was to be built on one of the rare unconstructed plots of land in an otherwise fairly densely inhabited group of neighborhoods. Located behind the public dispensary and maternity and the confessional catholic dispensary which lay wall to wall, the site was prone to collecting 
stagnating water during the rainy season and had been used as a household waste site. Although the creation of the school had been announced, the transfer lists had been completed, teachers had been transferred and the new principal had been appointed, at the start of the school year in October the area was still empty. Two months into the term, six classrooms were built of straw, two with the contribution of the district and the remaining four by the financial contribution of the parents whose children had been transferred to the school. Thus at the beginning of December 2006, the school was ready to receive the pupils and teaching could start. The blackboards, the few school benches placed in the classrooms and a small number of school books had been borrowed from neighboring schools. As the fourth public primary school in Saga, the newly established school was given the name 'Saga 4'. On what had been an empty piece of land there were now six straw classrooms which formed a semi circle. A wooden pole on which the Nigerien flag was hoisted and descended at the start and the end of the school day was placed in the middle of the semi circle, a seeming reminder of the status of the makeshift school as a public, or state, institution.

On my return to the field in 2007 the schoolhad taken on a more permanent appearance. The six straw classrooms had become thirteen as student numbers had increased. Fine grained sand filled the school yard, a small house in banco housed the guard, and young trees had been planted at the edges of the school yard. A water tap and waste bins had been installed by a Canadian project which had also constructed four latrines and a garbage incinerator at the extremity of the school yard. The intervention of the project was announced by a placard, one of the ubiquitous signs of development interventions. education system. The importance attached to these committees by the Ministry of Education and international donors is evident in the vast administrative organization from the national to the district level that has accompanied the implementation of the system of school committees ${ }^{6}$. Made up of representatives from the school administration, parents and the student body, the school committees were added to the already existing parents associations (APE - associations des parents d'élèves) as the 'steering committee' of the school. The responsibilities attributed to the school committees ranges from practically and administratively oriented tasks such as the acquisition or reception and management of school books and other teaching materials, the management of school funds including state subventions and community funds, and the maintenance of school infrastructure, to more community oriented tasks such as the promotion of schooling, especially the schooling of girls. In a context of scarce state resources the school committees are also a means of mobilizing local 
resources and are encouraged to raise resources through parental contributions in money or in kind, contributions from local NGOs, associations, or private benefactors.

In Saga 4 the members of the school committee and the parents' association had been elected and a handwritten list of members of the school committee and the parents' association was posted on the wall of the straw classroom that served as the office of the principal. Among the most active members of the school committee and the parents' association was the principal, a woman in her forties who had moved to Saga in the early 1990s, who occupied the post of secretary general of the school committee in her capacity as principal. Another active member was the president of the parents association who also occupied the post as president of the school committee ; a quiet and soft spoken man in his sixties from Saga Fondobon, according to the other committee members he was elected on the basis of his wisdom and availability. Given the lack of infrastructure, raising resources to meet the most basic needs of the school, such as the construction of classrooms in straw, became the most important role of the school committee.The 'action plan', which the school committee had been instructed to put together, was recorded in a notebook and kept by the principal. It included the construction of four straw classrooms, the acquisition of 25 school benches, the purchasing of textbooks, notebooks and crayons and a pharmaceutical box. In the end the contributions raised allowed for the construction of straw classrooms. Despite attempts to solicit the support of local 'big men' and politicians, the money raised came exclusively from the parents' financial contributions. The ability of the school committee to guarantee the daily functioning of the school thus depended on their ability to convince the parents to finance daily costs and investments in the school. In addition to the collection at the start of the school year, initiatives to collect money were also made during the course of the school year.

However, many parents criticized the frequent demands for money which added onto other expenses related to schooling (school material, notebooks, pens, clothes etc.). Overall interest in the activities of the school committee and the parents association was lukewarm. Placed in the larger context of the situation of public education this is not surprising. During my fieldwork, conversations about school and education - with pupils, parents and teachers - often ended in discussions about the deterioration of the public school and the poor quality of education. People pointed to the poor knowledge level of the pupils, unqualified teachers, frequent teacher strikes and lack of infrastructure. Moreover, whereas in the past a diploma or school leaving certificate might have held the promise of employment, this was no longer the case. The widespread unemployment of school graduates and the example of older children or siblings with high school and university diplomas but who were unemployed and struggled to make a living, caused people to question the advantage or use of education. All of these factors provided a shaky base for community participation and engagement. This point has been made by Maclure who, on the basis of a study in rural Burkina Faso, argues that the promotion of decentralization and local participation is based on "misplaced assumptions about continuing popular interest in formal education" when in fact increasing demand for time and resources for schooling coupled with diminishing prospects of private gain (employment) from education has lead to a dissatisfaction with public education (Maclure $1994: 240,245$ ).

School committees are presented by the Ministry of Education, international donors and NGOsas key components in the increased implication of parents in schools which in 
its turn will lead to a local appropriation of the school, the local community taking responsibility for its daily functioning, fostering local initiatives and better management of resources etc. Discourses about the school committee also assume a causal link between the active involvement of the beneficiaries (parents) and improved equity and quality. The promotion of school committees is clearly inscribed in the logic of community participation popular in development circles. The resolute promotion of community participation has been criticized for the underlying assumption that a community is homogenous or shares the same interests.

In Niger similar forms of community participation in the management of public services or goods through the creation of community committees have been introduced in domains such as public health care and water provision. In localities with a history of development interventions and public investments, these community committees were added onto already existing structures such as co-operatives and associations (Tidjani Alou 2009 :323). Studies of community management have pointed to the sometimes unexpected outcomes of such initiatives. In the case of village water pumps community management introduced by development projects was often transformed into informal, semi-private or private forms of management (Olivier de Sardan \& Dagobi $2000: 167$ ). And, attempts at sidelining the chieftaincy, in order to encourage transparency, democracy and the responsibility of the whole community, were unsuccessful (Olivier de Sardan \& Dagobi $2000: 153,163)$. However, Tidjani Alou has illustrated that community management (in this case of mini AEPs - mini adduction d'eau potable) can lead to the emergence of new social practices and "a notion of "public goods"' (Tidjani Alou $2009: 320$ ).

Like these studies, the situation in Saga 4 also lends little support to the assumption that community management automatically leads to collective mobilization and appropriation. The much heralded participation of the local community was more or less limited to monetary contributions. Interest to get involved in the management of the makeshift school was limited and was perceived as a burden.However, the school committee was functioning.And, although it had not succeeded in mobilizing the 'local community,' neither had it been appropriated for personal profit. In fact there were few resources in the school to compete for - to privatize or to monopolize. The school committee was headed by a couple of individuals, notably the principal and the president, who displayed a marked determination that 'their' school succeed. Having worked as a teacher in another primary school in Saga before being appointed principal of Saga 4, the principal was anxious to show that she couldshoulder the responsibility. Moreover for her it was an opportunity that was made possible because of the lack of infrastructure and resources etc. making the position unattractive to candidates who were better placed with personal contacts in the administrative echelons of the school inspection. The president, on the other hand, with no previous experience in local associations seemed to take the challenge in stride. His efforts in the school committee were acclaimed by other members of the parents' association and the school committee as well as by teachers and the principal. He was also backed by the neighborhood chief who, as I will describe in the next section, had taken on an active role in the school. 


\section{The legitimization of the traditional chieftaincy}

19 Saga 4 is situated in Saga Fondobon, one of the older quarters of Saga. The chief of Saga Fondobon, a tall, calm man in his seventies who was also the neighborhood imam, was implicated in the school from its creation. Chiefs in Niger have an officially recognized administrative status ${ }^{7}$. Integrated into the local administration during the colonial period, the administrative role of chiefs was maintained after independence. The responsibilities accorded to the chiefs ranges from the collection of taxes, acting as the representative of the community in relations with the administration and third parties, 'conciliating' in the case of conflict to acting as a development agent, actor and partner. Before the implementation of the decentralization reform in 2004, chiefs were the sole representatives of the statein many rural areas in Niger(Olivier de Sardan 1999). However, in Niamey with the early creation of a local urban government, the role of chiefs was reduced early on. As pointed out by Bernus: "Rapidly, this title [neighborhood chief] designated, without anything else, the one responsible for the collection of taxes" (Bernus 1965 :22, my translation).Today the key administrative role of chiefs in Niamey is still the collection of taxes ${ }^{8}$ as well as the role of neighbourhood representative. This role is mobilised in contacts with the local administration, most frequently the district, for instance in organising community meetings, sensitisation sessions, etc. Motcho describes the role of traditional chiefs in Niamey as being ambiguous. While the chiefs are perceived as increasingly irrelevant, both by the population and by the local administration (municipality), they hold a continuing influence on the territorial division of the capital (Motcho 2005).

20 In the case of Saga 4 the precarious situation of the school opened up a space for intervention for the neighbourhood chief. The chief frequently visited the school, often in the company of the president of the school committee. He also made trips to the district to solicit support for the school and contributed to the construction of the guard's one room house on the school grounds. Moreover a number of factors tied the school to the traditional chieftaincy or, rather, to the person of the neighborhood chief. Many of the key members in the community structures of the school, in particular the president and the vice president of the parents' association were close friends of the neighborhood chief. And the school was located in one of the founding quarters of Saga in which the neighborhood chief already maintained a visibility in neighborhood affairs which is not the case in all neighborhoods. The chief was widely respected both as a religious leader, as the neighborhood imam, and as a community leader. He had also played an important and active role in the health committee in the nearby health centre.

21 The neighborhood chief passed away in 2008. In conversations with parents, members of the school committee and the school administration, many recalled his dedication to the school. Following the death of the neighborhood chief, his son, who was later elected neighborhood chief, handled questions related to the school. The implication of the neighbourhood chief in the daily running of the school in a sense contributed to the legitimization of the traditional chieftaincy. Through his involvement in the school the chief fulfilled part of the official attributions of the traditional chieftaincy as an 'agent of development' (Motcho 2005). This implication was made possible, or at least reinforced, due to the absence of state support for the school. The support of the neighbourhood chief was also welcomed by the school committee and the principal, 
who felt that they had been left to fend for themselves. The interests of the school committee and the neighbourhood chief thus converged. Moreover the chief was an important ally in convincing the parents to involve themselves in the daily management of the school.

of all of the actors that were to intervene in the school, the chief, who at times acted as an extension of the school committee, was the closest in terms of 'social proximity'. This was a result of both his relation with the members of the school committee, and his role as neighborhood representative.In the next section of the article I will describe the intervention of the district and a development project in the school, situations in which the school committee - though assigned the role of intermediary between different partners of the education system at the local level - had little influence or room for manoeuvre.

\section{The district and the construction of straw classrooms}

The district intervened in the school mainly through the construction of straw classrooms, which as I will describe below came to involve political and economic stakes. Saga is part of District Four of the urban municipality of Niamey. The district covers the eastern part of the capital and is made up of mostly peri-urban neighborhoods, a few villages and a couple of residential neighborhoods. The district office, a somewhat derelict two story building which is shared between District Three and District Four, is situated near the boundary between the two districts, a taxi ride away from Saga. Following a slate of different proposals during the late 1990s and early 2000 aiming to decentralize the management of the capital - to valorise local resources and to increase the implication of the population (Motcho 2004) - Niamey was finally divided into five districts. In the past the mayors of the districts were nominated. However, with the municipal elections in July 2004, the mayors were elected.

The district is responsible for giving material support to the primary schools and kindergartens in its constituency ${ }^{9}$, a considerable responsibility given the number of pupils (Charlier \& Pierrard $2000: 41$ ). The district struggled to fulfil its responsibilities vis-à-vis the schools due to financial problems attributed by district officials to the difficulty of collecting taxes and to the unreliable financial support of the central government. The construction of classrooms in straw makes up approximately one third of the total education budget. It is also the most visible action of the district given the constantly increasing number of straw classrooms in the capital. According to the district official responsible for the education sector, at the beginning of the school year 2006-2007 the district had received requests via the school inspection for the construction of over a hundred classrooms. As the district was unable to build all classrooms needed, the final responsibility for the construction of classrooms was placed on the shoulders of the individual schools and ultimately on the parents.

For schools such as Saga 4 the preparation of the start of each school year was marked with uncertainty about the number of classrooms that would be provided by the district. However the organization of the construction of classrooms at the local level seemed to open up a space for negotiation as district advisors (elected members of the district council) were frequently given the contract for the construction of straw classrooms. According to one advisor in Saga this allowed the district to reduce the cost of the construction and to postpone the payment as the advisors constructed the 
classrooms on credit. However the members of the school committee in Saga 4 claimed that they would be able to construct a classroom for even less, and thus argued that they could build more classrooms if they were to be granted the contract instead of the district advisors. One of the members of the school committee recounted their unsuccessful attempts at negotiating with the district advisor who had been given the contract for the construction of classrooms. The following year they tried to bypass the advisor by approaching a district official who lived in Saga. However, this attempt was also unsuccessful as the contracts had already been divided up between two district advisors, both from Saga.

The rivalry over the construction of classrooms is illustrative of the monetary and political stakes involved. The granting of contracts to the district advisors benefited the district advisors as they, through the construction of classrooms, contributed something to the neighbourhood. This evidence of their political actiongave them a certain visibility for their ability to direct investments to the neighbourhood (even if only temporary classrooms in straw). At the same time, the budgeted cost of the construction and the real costs also left a possibility (margin) for monetary benefits.

The arrangement was also beneficial for the district. First, the classrooms were sometimes constructed on credit guaranteeing the district that the classrooms would be in place at the beginning of the school year. This was important for the credibility of the district which still had a long way to go in convincing people to pay taxes. Second, it allowed the district or the mayor to keep the district advisors who had voted him into office on his side.In this context the school had little chance of accessing the contract despite their attempts to negotiate through local contacts from the district advisors to a district official.

\section{An elusive development project}

In the face of faltering state support and an uncertain support from the district, hope was placed on the possibility that a development project might support the school, a common ambition in many localities in Niger. On my return to the field for a second period of fieldwork, members of the school committee told me with exaltation and relief about the promised construction of thirteen furnished classrooms. A delegation had come to the school to take the measurements of the area and plans had been made of where to relocate the school during the period of the construction. The customary owners of the land including the canton chief among others had signed a paper as a guarantee that the land had been ceded to the school. I tried to inquire more about the project but people had little information and it was simply referred to as 'the Chinese' ( 'les chinois'). According to staff at the school inspection, the contacts with the project always passed through the Ministry of Education. Following the first flurry of activities months passed and the project was nowhere in site. Responses to questions, if there was any news about the construction, became increasingly dejected. It was only during a visit to the district's primary school inspection in another errand that the principal of Saga 4 was told that the project had in fact been transferred to another school.

The explanation given for this turn of events was that 'the Chinese' had wanted a completely empty space on which to build the school. However, a Canadian project had already installed a water tap, waste bins, a garbage incinerator and four latrines on the school grounds. The latrines built by 'the Canadians' would thus have to be destroyed 
for the project to go ahead. In Saga the news seemed to confirm the already creeping suspicions that the project had been co-opted to benefit another locality. Nonetheless the principal contacted an influential resident, originally from Saga with a long career in international development cooperation and the state administration, who promised to meet personally with the Minister of Education to plead the case of Saga 4. Once again the district official living in Saga was contacted but he claimed that it was out of his range of action as the district had not been involved in the discussions with the project. Finally, the efforts were unsuccessful to the great disappointment of the principal, teachers and members of the school committee.

For the second year in a row, a couple of weeks before the end of the school year and in anticipation of arrival of the rainy period, the classrooms were once again taken down. The president dismantled the straw classrooms with the help of a couple of young recruits. The wooden supports and straw mats along with the few school benches and blackboards were transported by the guard on a donkey cart to Saga 1 where they were stored in a padlocked classroom to be reused the following school year. Only the latrines, the tap, the wastebaskets and the guard's one room house remained, as well as the placard raised by the Canadian project withthe arrow painted below the name of the primary school pointing into a seeming void.

31 This episode is illustrative of the hopes that were attached to the promised intervention of the development project and construction of classrooms which would create certainty and permanence. It is also revelatory of the school committee's limited room for negotiation or influence. Both the Chinese and the Canadian projects had come 'from above' channelled as they were through the Ministry of Education and with barely any contact with the school committee or the district. However, although they had been left out of the process and seemed to have been the last to be informed about the suspension of the project people in Saga involved in the school did everything in their power to alter the decision.

\section{Discussion}

[...] our differentiation between image and practices facilitates bringing the ambiguities and contradictions of state domination to the fore. For example, it is possible that the image of the state can persist through long periods in which practices contradict that image (Migdal \& Schilchte 2005 :35)

This article has attempted to analyse practices and representations surrounding public education provision in the case of a public primary school. What emerges from these episodes and descriptions of the daily life - filled with ups and downs, hope and disappointment - of one particular primary school is the sense of uncertainty and impermanence that characterises the daily management of the school.In the case of Saga 4 the combination of a policy of decentralization and community participation, and the lack of infrastructure opened up for the intervention of a number of different actors in the school. The case is revelatory of the logics that motivate these actors such as the legitimization of the traditional chieftaincy and the political and financial stakes surrounding the construction of straw classrooms. It is also illustrative of the difficult mobilization of the so-called 'local community' and of the limited influence of community structures such as the school committee despite the emphasis that is placed on local participation in current education policy. 

Education is an important sector of the state. A basic public service, it generally absorbs a significant part of the national budget and teachers are the largest group of state employees. School is also important as a means for the production of the idea of the state. First, schools through their physical presence demarcate the territory or space of the state (Wilson 2001 :313). As pointed out by Bierschenk, in many African villages the state is embodied by the school - “...which distinguishes itself from neighboring constructions by its localization and its appearance, if not by the presence of a flag in the school yard and the uniforms of the pupils" (Bierschenk, 2007:269, my translation).Second,theschool is "an institution that relays ideas about state, nation and citizen" (Wilson 2001 :313). Although this article has focused on the 'practical' aspects of public education provision and school management at the local level I want to suggest that it is still possible to say something about the relation between education and the state. ${ }^{10}$

(inked people's experiences of constant medicine shortages, inefficiency, expensive prescriptions and corruption with experiences of the post colonial state (Masquelier 2001). She argues that the views of the dispensary as an empty and inefficient institution are part of the discursive construction and deconstruction of the state by rural dwellers (Masquelier 2001 :270).In Saga people talked about the "disengagement of the state" when it comes to education. They found evidence for these claims among the increasing personal costs of education for school books, school material, uniforms etc., inadequate infrastructure, frequent teacher strikes and a worsening quality of education, etc. They compared the current state of affairs to the past when the majority of costs related to education were taken care of by the state. Statements, such as "the state has abandoned school" and "we have done everything and the state has done nothing", abounded in discussions about school and especially in relation to Saga 4. Such comments could be interpreted as an indication that the school is less obviously " la chose de l'État' (Lange $2003: 147$ ) - thought of as belonging to the state - as education provision is ensured by a diversity of 'non state' actors.

However, I want to suggest that despite, or maybe because of, the perception that the state is disengaging from education, people continue to bring forth the idea of the state as the ideal provider of social or public services, which is why it makes sense to talk about or decry the disengagement of the state. As Nielsen has argued in the case of a relocation process in Maputo, people continue to invest themselves in the idea of the state even in the relative absence of the state and the failure of the authorities to regularize and to equip the neighborhood (Nielsen 2007). Thus at the same time as public education provision is being reconfigured or decentralized to include a number of non state actors - from parents, to the traditional chieftaincy to district advisors and international development aid - the idea of the state as the ideal provider of public education remains strong.

1. During the fieldwork I was assisted by Fatimata Moussa during the first period of fieldwork and Amadou Boubacar during the second period of fieldwork, both of whom provided invaluable input. My stay in Niamey was also greatly facilitated by LASDEL (Laboratoire d'Etudes et de Recherches sur les Dynamiques Sociales et le Développement Local). The research was generously funded by Swedish International Development Cooperation Agency (Sida).

Bulletin de l'APAD, 31-32 | 2010 


\section{BIBLIOGRAPHY}

Bernus, S. 1969. Particularismes Ethniques en Milieu Urbain : L'Exemple de Niamey. Paris : Memoires de l'Institut d'Ethnologie.

Bierschenk, T. 2007. L'éducation de base en Afrique de l'Ouest francophone : Bien privé, bien public, bien global. In Une anthropologie entre rigueur et engagement : Essais autour de l'oeuvre de JeanPierre Olivier de Sardan (eds) T. Biershenk, G. Blundo, Y. Jaffré \& M. Tidjani Alou. Paris : Karthala.

Blundo, G. \& J.-P. Olivier de Sardan (eds) 2006. Everyday Corruption and the State : Citizens and Public Officials in Africa. London and New York : Zed Books.

Blundo, G. \& P.-Y. Le Meur 2009. Introduction : An Anthropology of Everyday Governance : Collective Service Delivery and Subject Making. In The Governance of Daily Life in Africa: Ethnograpic Explorations of Public and Collective Services (eds) G. Blundo \& P.-Y. Le Meur. Leiden \& Boston : Brill.

Charlier, J.-E. \& J.-F. Pierrard 2000. Systèmes décentralisés dans l'éducation sénégalaise, burkinabé et malienne. Autrepart 17, 29-48.

Daouda, A, A.A.I. Daouda \& H Souley 2001. Le Niger : Politiques éducatives et système éducatif actuel. In La Demade d'éducation en Afrique : Etat des connaissances et perspectives de recherche (eds) M. Pilon \& Y, Yaro.

Henaff, N. 2003. Quel financement pour l'Ecole en Afrique ? Cahiers d'Études africaines 169-170, XLIII (1-2), 167-188.

Jaffré, Y. \& J.-P. Olivier de Sardan (eds) 2003. Une médecine inhospitalière : Les difficiles relations entre soignants et soignés dans cinq capitales d'Afrique de l'Ouest. Paris : Karthala.

King, K. 2007. Multilateral agencies in the construction of the global agenda on education. Comparative Education 43 (3), 377-391.

Lange, M.-F. 2003. Ecole et mondialisation. Vers un nouvel ordre scolaire ? Cahiers d'Études africaines169-170, XLIII (1-2), 143-166.

Maclure, R. 1994. Misplaced Assumptions of Decentralization and Participation in Rural Communities : Primary school reform in Burkina Faso. Comparative Education 30 (3), 239- 254.

Bulletin de l'APAD, 31-32 | 2010 
Masquelier, A. 2001. Behind the Dispensary's Prosperous Façade : Imagining the State in Rural Niger.Public Culture 13 (2), 267-291.

Meunier, O. 2000. Bilan d'un siècle de politique éducative au Niger. Paris : L'Harmattan.

Migdal, J. \& K. Schlichte. 2005. Rethinking the State. In The Dynamics of States: The Formation and Crisis of State Domination (ed.) K. Schilchte. Aldershot : Ashgate.

Motcho, K.H. 2004. La réforme communale de la communauté urbaine de Niamey (Niger). Revue de géographie alpine 92 (1), 111-124.

Motcho, K.H. 2005. Urbanisation et rôle de la chefferie traditionnelle dans la communauté urbaine de Niamey. Les Cahiers d'Outre Mer 229, 73-88.

Nielsen, M. 2007. Filling in the Blanks: The Potency of Fragmented Imageries of the State. Review of African Political Economy 34 (114), 695-708.

Olivier de Sardan, J.-P. 1999. L'espace public introuvable : Chefs et projets dans les villages nigériens. Tiers-Monde 40 (157), 139-167.

Olivier de Sardan, J-P. 2004. Etat, bureaucratie et gouvernance en Afrique de l'ouest francophone. Politique Africaine 96, 139-162.

Olivier de Sardan, J.-P. 2005. Classic ethnology and the socio-anthropology of public spaces : New themes and old methods in European African Studies. Africa spectrum 40 (3), 485- 497.

Olivier de Sardan, J.-P. \& A. Dagobi 2002. La gestion communautaire sert-elle l'intérêt public ? Le cas de l'hydraulique villageoise au Niger. Politique Africaine 80, 153-168.

Tidjani Alou, M. 1992. Les Politiques de Formation en Afrique Francophone : Ecole, Etat et Sociétés au Niger. Thèse de doctorat, Bordeaux.

Tidjani Alou, M. 2009. Public goods and the management of collective infrastructure : the case of the drinking-water supply systems in the Maradi region of Niger. In The Governance of Daily Life in Africa: Ethnograpic Explorations of Public and Collective Services (eds) G. Blundo \& P.-Y. Le Meur. Leiden and Boston : Brill.

Wilson, F. 2001. In the Name of the State? Schools and Teachers in an Andean Province. In States of Imagination : Ethnographic Explorations of the Postcolonial State (eds) T.B. Hansen \& F. Stepputat. Durham and London : Duke University Press.

\section{NOTES}

2. Of the eight MDGs two directly address education. Goal 2 is to 'achieve universal primary education' and the target is to "ensure that by 2015 children everywhere, boys and girls alike, will be able to complete a full course of primary schooling". Goal 3 is to "promote gender equality and empower women" and the target is to "eliminate gender disparity in primary and secondary education preferably by 2005 and in all levels of education no later than 2015".

3. Similar reforms aimed at introducing a rational and effective management of resources in the education sector had already been introduced in the 'Education Projects' of the 1980s and early 1990 s backed by the World Bank and the IMF (Meunier, $2000: 166$ ).

5. Figure based on the estimates of population growth of the district for the year $2007(29,556)$. This includes the population of the neighbourhoods Saga Fandobon, Saga Gassia Kwara, Saga Gongou, Saga Sambou Kwara, Saga Kourté (and Pays Bas) and Saga Dababanda. 
7. The role of chiefs is established in an ordinance on the 'status of the traditional chieftaincy in Niger' passed in 1993 (Ordonnance $\mathrm{N}^{\circ}$ 93-28 du 30 mars 1993 portant statut de la chefferie traditionnelle du Niger).

8. The taxe de voirie, a 'council tax' used for the maintenance of infrastructure, roads etc. which are collected on the behalf of the district. The chiefs receive $10 \%$ of the amount collected.

9. Examples include the construction of classrooms in straw, the provision of furniture for the schools (school desks, desks, chairs, blackboards, storage cabinets...), the renovation of classrooms and of school furniture, support to the primary school inspection in the organization of the end of the year exams and the transportation of students from villages/peripheries to the examination centers, etc.

\section{ABSTRACTS}

In Niger the decentralization of the education system and the implication of local communities in the management and financing of education services is the dominant logic of national education policy promoted by international donors. In the article I examine the mobilization of local actors in public education provision. I do this using an ethnographic study of the daily management of a newly established public primary school in peri-urban Niamey. The case study illustrates the diversity of actors, from traditional chiefs to district advisors and international development projects that are implicated in the provision of public education as well as the different logics and stakes at play. It is also revelatory of the limited room for manoeuvre of the 'local community' organized in school committees in ensuring the day-to-day functioning of the school. Finally it is argued that at the same time as education provision is in part taken over by local actors the idea of the state as the ideal provider of public education remains strong.

Au Niger la décentralisation du système éducatif et l'implication des communautés locales dans la gestion et le financement des services éducatifs constitue la logique dominante des politiques publiques de l'éducation nationale promues par les bailleurs de fonds internationaux. Dans cet article, j'examine la mobilisation des acteurs locaux dans l'éducation publique nigérienne à travers une étude sur la gestion quotidienne d'une école nouvellement créée dans une zone périurbaine de Niamey. Cette étude de cas décrit la diversité des acteurs : des chefs traditionnels, des conseillers municipaux, des projets de développement, etc. Elle inclue des logiques et enjeux différents. L'étude démontre que la marge de manœuvre du comité de gestion local reste limitée en ce qui concerne le fonctionnement de l'école. En conclusion, l'article propose qu'en même temps que la provision de l'éducation est prise en charge par des acteurs locaux, l'idée de l'État en tant que fournisseur idéal de l'éducation publique reste forte.

\section{AUTHOR}

\section{GABRIELLA KÖRLING}

PhD-candidate in Cultural Anthropology at Uppsala University : gabriella.korling@antro.uu.se 